\title{
IMPACT OF IDOL IMMERSION ON WATER AND SEDIMENT QUALITY IN THE RIVER MAYURAKSHI AT SAINTHIA, DIST. BIRBHUM, WEST BENGAL, INDIA
}

\author{
Astom Mondal ${ }^{* 1}{ }^{\mathbb{}}$, Sankar Narayan Sinha ${ }^{2}$ \\ ${ }^{* 1}$ Research Scholar (CSIR-JRF), Department of Botany, University of Kayani, West Bengal-741235, \\ India \\ 2 Professor and Head, Microbiology and Virology Section, Department of Botany, University of \\ Kalyani, West Bengal-74235, India
}

DOI: https://doi.org/10.29121/ijetmr.v7.i7.2020.718

Article Citation: Astom Mondal, and Sankar Narayan Sinha. (2020). IMPACT OF IDOL IMMERSION ON WATER AND SEDIMENT QUALITY IN THE RIVER MAYURAKSHI AT SAINTHIA, DIST. BIRBHUM, WEST BENGAL, INDIA. International Journal of Engineering Technologies and Management Research, 7(7), 50-57. https://doi.org/10.29121/ijetmr.v7 i7.2020.718

Published Date: 20 July 2020

\section{Keywords:}

Idol Immersion

River Mayurakshi

Heavy-Metals

Water Pollution

Temperature

\section{ABSTRACT}

The country of India is the unique where different cultural heritage as well as festivals were found. Mainly the West Bengal state is known as various religious festivals, but Durga Puja is one of the biggest and end of this festival idol are immersed in the water bodies. Sainthia town found in the district of Birbhun, West Bengal, India which is present in the south bank of the Mayurakshi river. The idol immersion mainly effect on water as well as sediment quality of this river Mayurakshi near railway bridge at Sainthia. The study will be discussed for immersion effect of this sampling station, because in this point totally Sainthia town Durga idols were immersed. The water and sediment samples were collected at 7:30 am on 9th October 2019 during pre-immersion (before immersion) and 7:30am on 10th October 2019 during the post immersion (after immersion) in this time of periods. Mainly, the Durga idols are been made up by nonbiodegrable substances such as clay, plaster of paris, cloths, paper woods, thermocols, jutes and synthetic paints etc. these are mainly toxic substances. Over all the used materials in making of idol, the thermocol is nonbiodegradable while paints contained highly toxic heavy metals like $\mathrm{Cr}$, $\mathrm{Cd}$ and $\mathrm{Pb}$. In this study has been made to analysis the physicochemical parameters like temperature, pH, TS, TDS, TSS, EC and three heavy metals like $\mathrm{Cr}, \mathrm{Cd}$ and $\mathrm{Pb}$ on the collected water and sediment samples of the Mayurakshi river on before and after idol immersion periods of near railway bridge sampling station. The analysed results by based on various physicochemical parameters showed that the after immersion in the river Mayurakshi increases concentration of heavy metals and changes other physicochemical parameters of the both water and sediment samples. Finally concluded that, these changes of different parameters are harmful for aquatic life and human beings as well as the level of water pollution highly increases in this Mayurakshi river. So, the huge religious activities mainly causes of the water pollution where huge disturbing aquatic ecosystem. 


\section{INTRODUCTION}

In India is multi-cultural country than other countries for different festivals. The one of most important cultural festival for Indian people is Durga Puja which is celebrated by mainly West Bengal peoples in India and other countries for worshipping Goddess Durga during the period of Navaratri. This year, Durga Puja 2019 started on $5^{\text {th }}$ October and continued till $8^{\text {th }}$ October. However, Durga Puja 2019 celebrations at Sainthia, Birbhum district started $5^{\text {th }}$ october and Visarjan (immersion in river water) on $9^{\text {th }}$ October on river Mayurakshi. However, after festivals idols are immersed in the directly water bodies of the rivers, ponds and lakes. Durja puja is the most prominent festivals which celebrated mainly by the hindu communities and the river Mayurakshi is the major river of Jharkhand and West Bengal which is most important in the West Bengal lifeline of small town like Sainthia, Suri etc. and native villages.

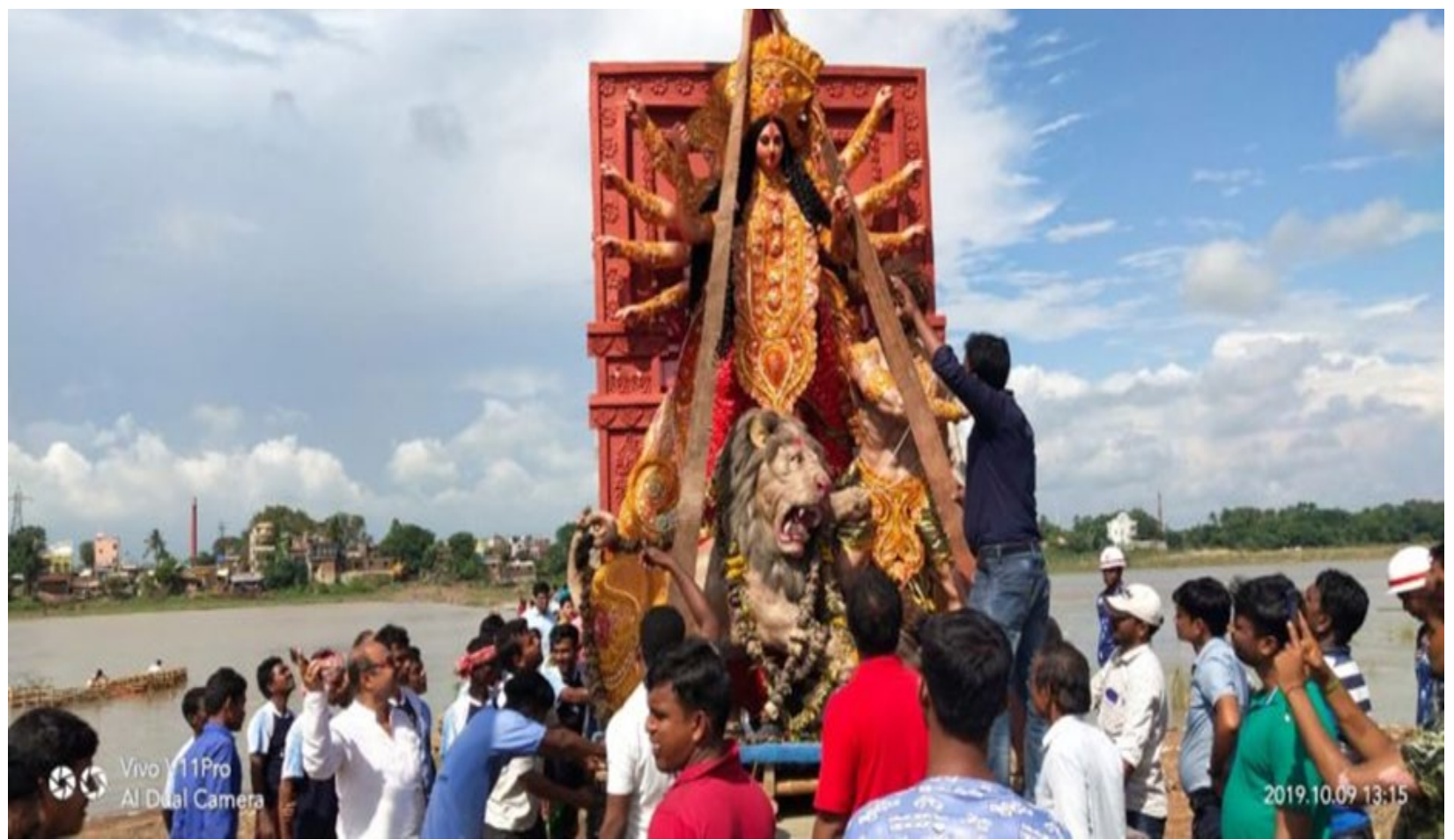

Figure 1: Idol immersion of Durga in the Mayurakshi near Bijoya ghat at Sainthia town, Birbhum district, West Bengal in India.

This river are originated form the Chota Nagpur Plateau and flow down into West Bengal in the districts of Birbhum and Murshidabad. The river Kopai, Bhrahmani, Dwaraka and Brakeswar tributaries are mixed in this river. Fially, the river Mayurakshi are mixed in the river Hoogly (Bhagirathi/Ganga) at Jalangi, Murshidabad district, total lenghth of this river is $250 \mathrm{~km}$. Some of the historically important of the Mayurakshi river water uses in various purposes by the peoples at Sainthia and nearest native villagers. Some of the peoples are used in drinking purposes. The seriously major impacts on the directly environment by idol immersion. It disturbs on the environmental as well as ecological balance and effect on the water bodies and river bed. After the immersion, polluting water are mainly affecting the various plants as well as animals. The idols mainly made by non-biodegradable substances like as plastic, cement, plaster of paris, cloth, paper wood, thermocols, jute and are painted by the chemical colours which are mainly toxic and harmful for aquatic ecosystem as well as human beings. When these substances are come and contact with directly water and river bed which becomes poisonous. These poisonous substances spread by flowing of water and finally affecting all forms of aquatic life present in the water bodies as well as beds in the river Mayurakshi. Thousands of different sizes Durga idols reaching up to 10-25 feet were immersed in the water bodies in every year of the river Mauyurakshi at Sainthia near railway bridge, Birbhum district, West Bengal in India. 
Impact of Idol Immersion on Water and Sediment Quality in The River Mayurakshi At Sainthia, Dist. Birbhum, West Bengal, India

\section{MATERIALS AND METHODS}

The sediment and water samples was collected from near railway bridge (23.9555N, $\left.87.6803^{\circ} \mathrm{E}\right)$ at Saintha town near railway bridge where various idols are immersed and this site immersed of idol at pre immersion dated on $9^{\text {th }}$ October 2019 and post immersion dated on $10^{\text {th }}$

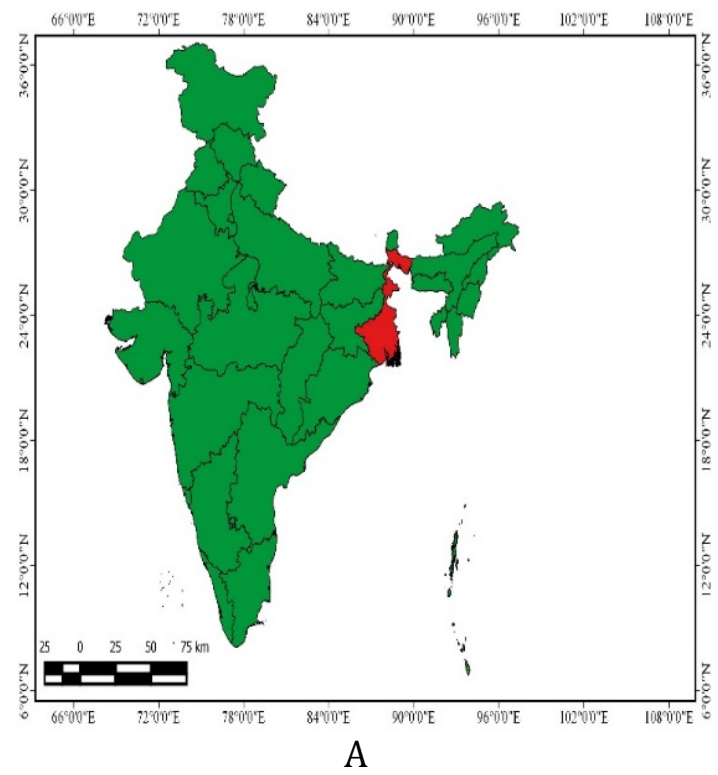

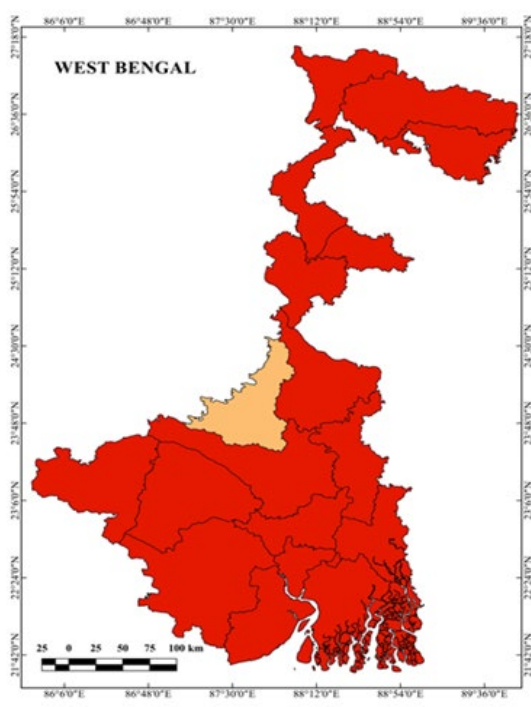

B

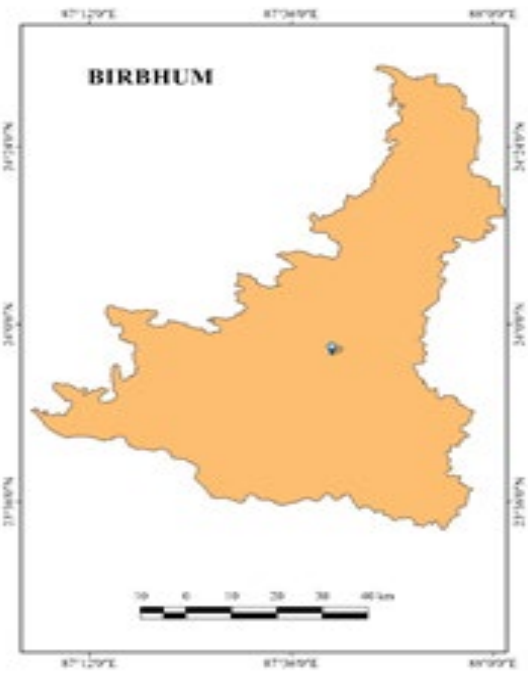

C

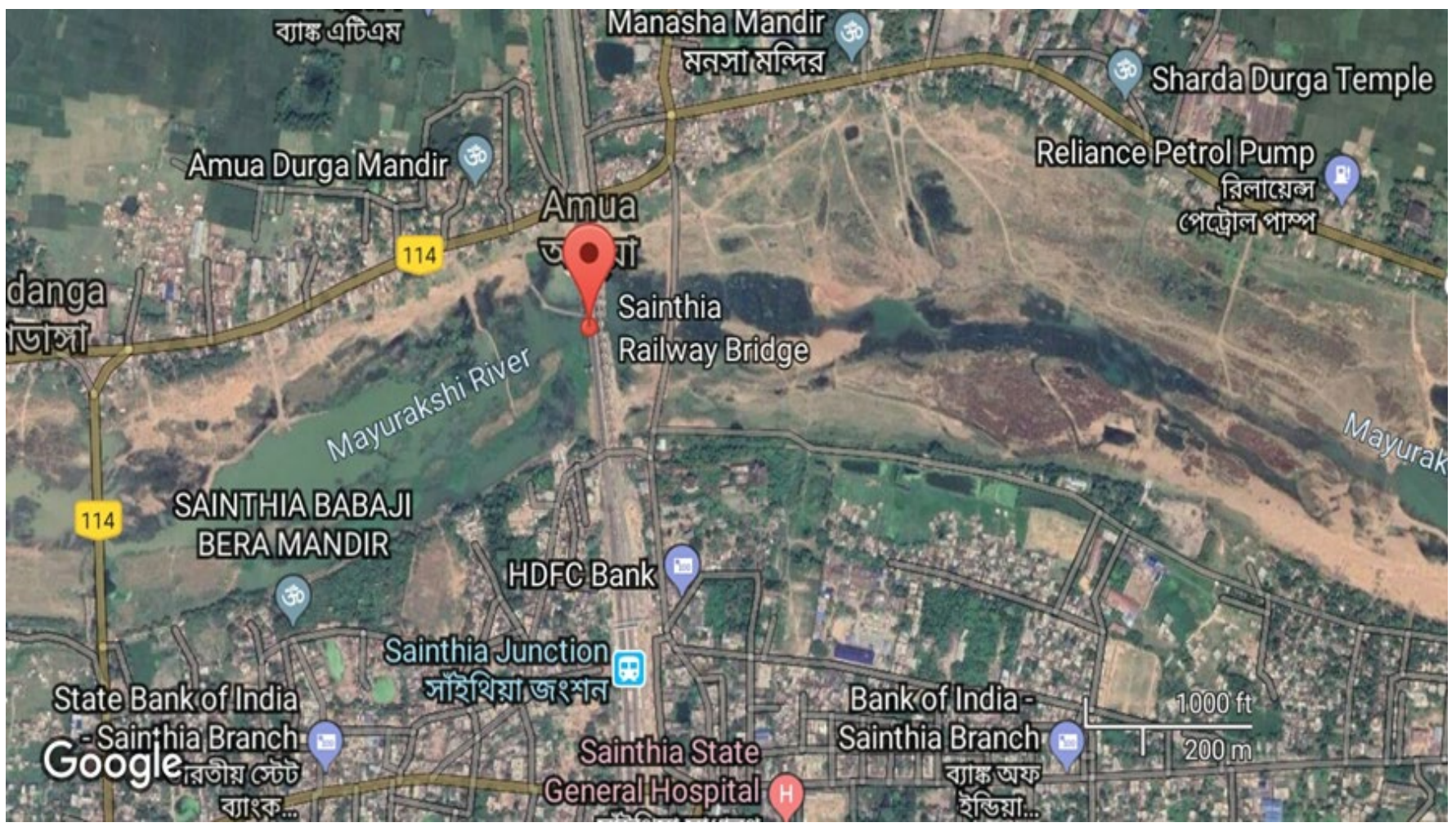

$\mathrm{D}$ 


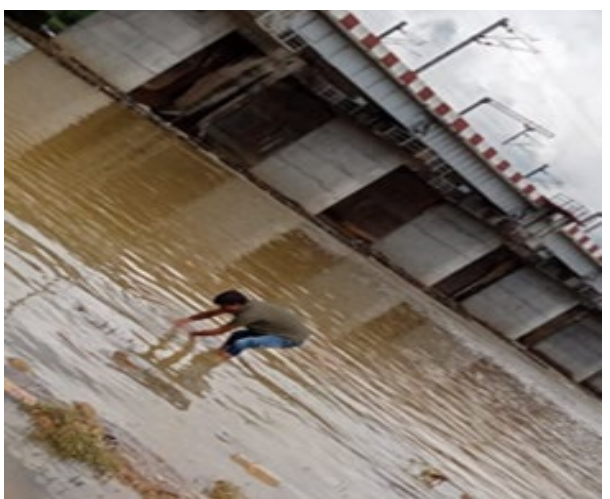

E

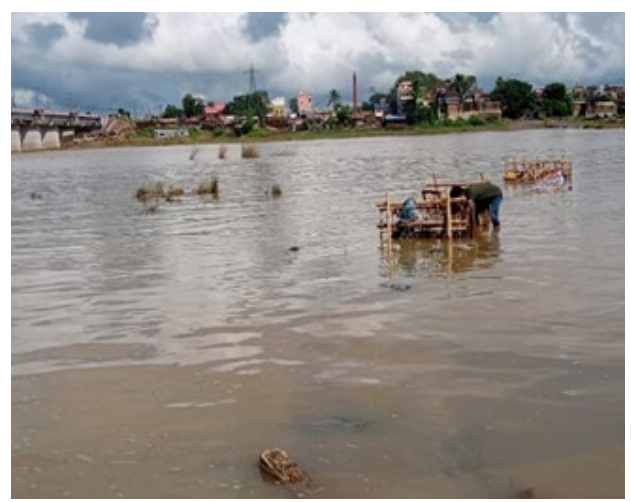

$\mathrm{F}$

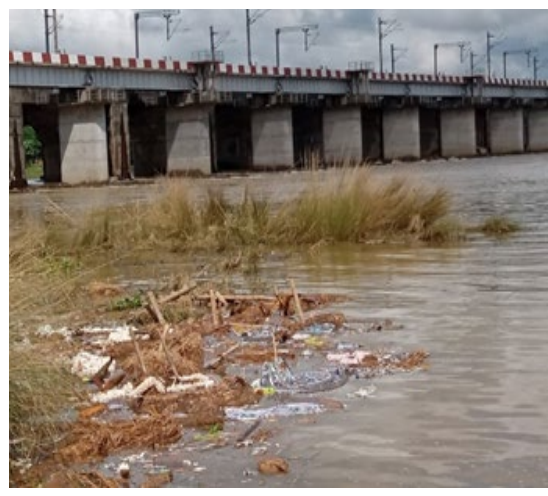

G

Figure 2: Map showing sampling stations and geological settings of the study area [A. India map showing West Bengal, B. West Bengal map showing Birbhum district, C. Birbhum district map showing sampling station, D. Sampling station near railway bridge at Sainthia (source: Google map), E. Collection of before immersion, F. Collection of after immersion and G. After immersion waste materials immersed in the river].

October at 7:30 am in the period of time Durga puja. The water and sediment samples collected for analysing some physicochemical parameters like $\mathrm{pH}$, temperature TS, TDS, TSS, EC and three heavy metals as $\mathrm{Cr}, \mathrm{Cd}$ and $\mathrm{Pb}$ were analysed according to standard methods [1], [2]. The heavy metals were preserved by standard $\mathrm{HNO}_{3}$ digestion method [3]. Extracts were analysed for $\mathrm{Cr}, \mathrm{Cd}$ and $\mathrm{Pb}$ using Atomic Absorption Spectrophotometer.

\section{RESULTS AND DISCUSSION}

The different parameters of the results of investigation in the sampling point have been shown in figure 3 (AF). These data revealed that the status of water and sediment quality of the river Mayurakshi is disintegrated due to the immersion of Durga immersed idols.

pH: The pH i.e. concentration of hydrogen ion was analysed by the $\mathrm{pH}$ scale and analysing values changed in both collected water and sediment samples. Hydrogen ion concentration is very important for environmental as well ecological factorisation which is causes by used organic and inorganic substances for preparation of idols. Nearly neutral pH i.e. value 7.0 of water and sediment in both cases was regulated by carbon dioxide and bicarbonates. The measured value of river water showed in pre immersion 7.45 and post immersion 6.80, sediment showed pre immersion 8.20 and post immersion 7.10 respectively (Figure 3-A), however it was below the permissible limits. For this sampling station, the levels of $\mathrm{pH}$ are decrease $8.72 \%$ in water and $13.41 \%$ in sediment respectively.

Temperature: The temperature of the river water is another important physicochemical factor for river suitable condition. The recent investigation, temperature of the river water was found to be pre immersion $29.34 \circ \mathrm{C}$ and post immersion $30.5^{\circ} \mathrm{C}$, sediment temperature was found to be pre immersion $31.33^{\circ} \mathrm{C}$ and post immersion $31.84^{\circ} \mathrm{C}$ of this point respectively (Figure 3-B). The results showed in this investigation temperature was increased in both water and sediment samples by the chemical reaction as well as biological activity reduced by solubility of gases in river water. The levels of temperature are increase $3.95 \%$ in the water and $1.62 \%$ in sediment in this river. This variation revealed significantly higher values in post immersion and lower in pre immersion but it was below the permissible limits.

Total Solids (TS): During the investigation of the Total Solids were found to be higher at Sainthia near railway bridge site. In this study, water total solids was found in the pre immersion period $1200 \mathrm{mg} / \mathrm{L}$ and post immersion period $2600 \mathrm{mg} / \mathrm{L}$ (Figure 3-C). This variation revealed significantly higher values in post immersion and lower in pre immersion. However, in the pre immersion value of water shows that bellow the permissible limit but in post immersion periods time values shows higher than the permissible limit in the water of the river Mayurakshi.

Total Dissolved Solids (TDS): The total dissolved solids was referring mainly the presence of various organic substances, inorganic ions concentration and in both cation-anions such as $\mathrm{Mg}^{++}, \mathrm{Ca}^{++}, \mathrm{K}^{+}, \mathrm{Na}^{+}, \mathrm{Cl}^{-}, \mathrm{SO}_{2}{ }^{4-}, \mathrm{HCO}_{3}^{-}$and $\mathrm{CO}_{3}{ }^{2-}$ in the aqueous solution. The analysed value of total dissolved solids in the water after immersed of idols was found in $1400 \mathrm{mg} / \mathrm{L}$ and before immersion $600 \mathrm{mg} / \mathrm{L}$ respectively (Figure 3-C) i.e. 133.33\% increase post immersion of Durga idols. If compared to pre immersion, TDS has generally increased at sampling point. Finally shows that the 
Impact of Idol Immersion on Water and Sediment Quality in The River Mayurakshi At Sainthia, Dist. Birbhum, West Bengal, India

TDS value in both pre and post immersion higher than based on the standards of water quality permissible limit [20], [21].

Total Suspended Solids (TSS): Total suspended solids (TSS) is the dry weight of the suspended particles in the water. Most of the suspended solids are made by the inorganic materials, but in some cases decomposed organic materials can also contribute to the TSS concentration of water. However, chemicals are precipitated form immersed idols which generally increasing the value of suspended solids particle. So, total suspended solids are most significant factor for observation of suitable water quality clarification. In this study, TSS was found in the period of pre immersion $600 \mathrm{mg} / \mathrm{L}$ and post immersion $1200 \mathrm{mg} / \mathrm{L}$ (Figure 3-C) time periods of the river Mayurakshi water. This variation revealed significantly higher values in post immersion and lower in pre immersion, but these values are higher than the BIS \& ICMR standards permissible limit [20], [21].

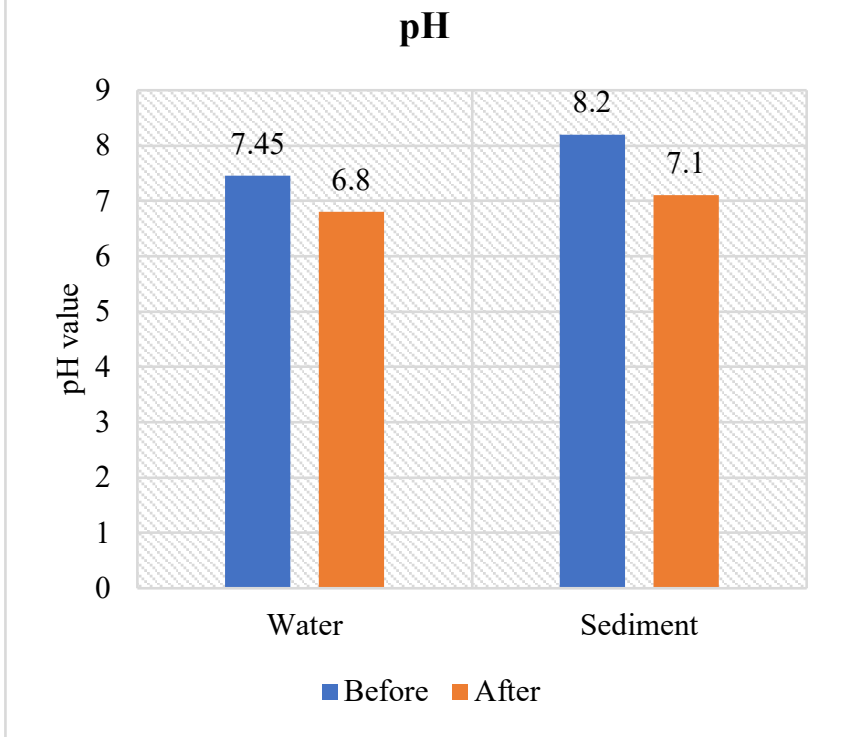

A

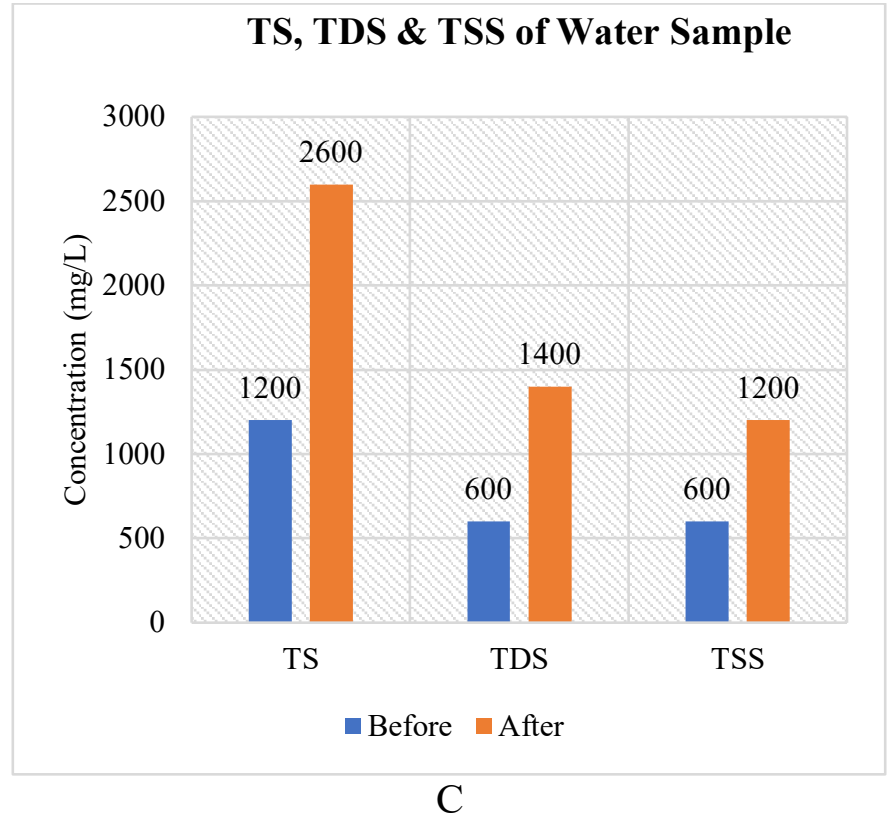

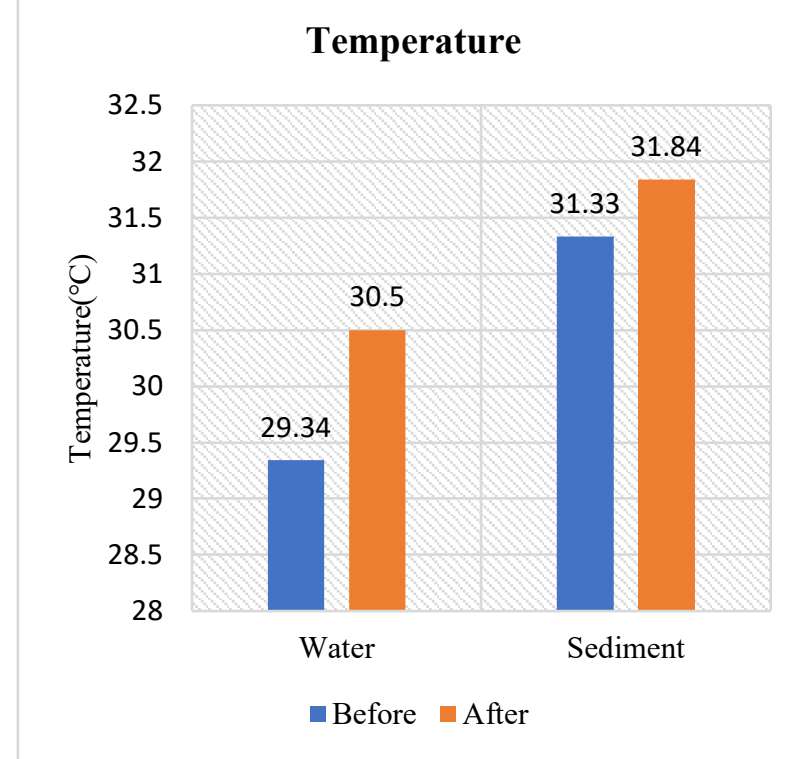

B

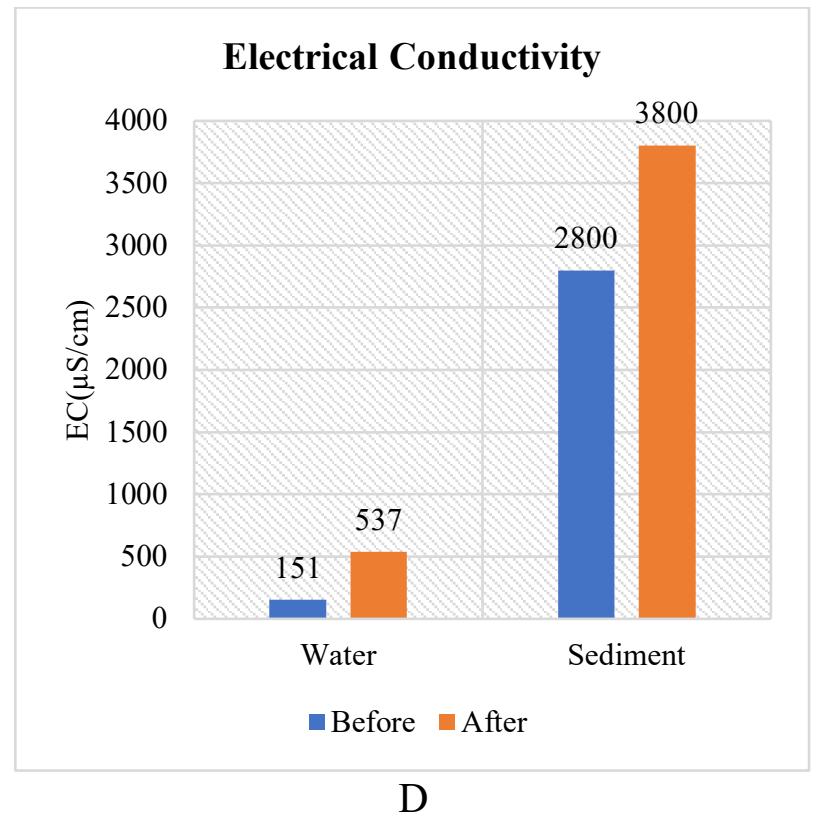



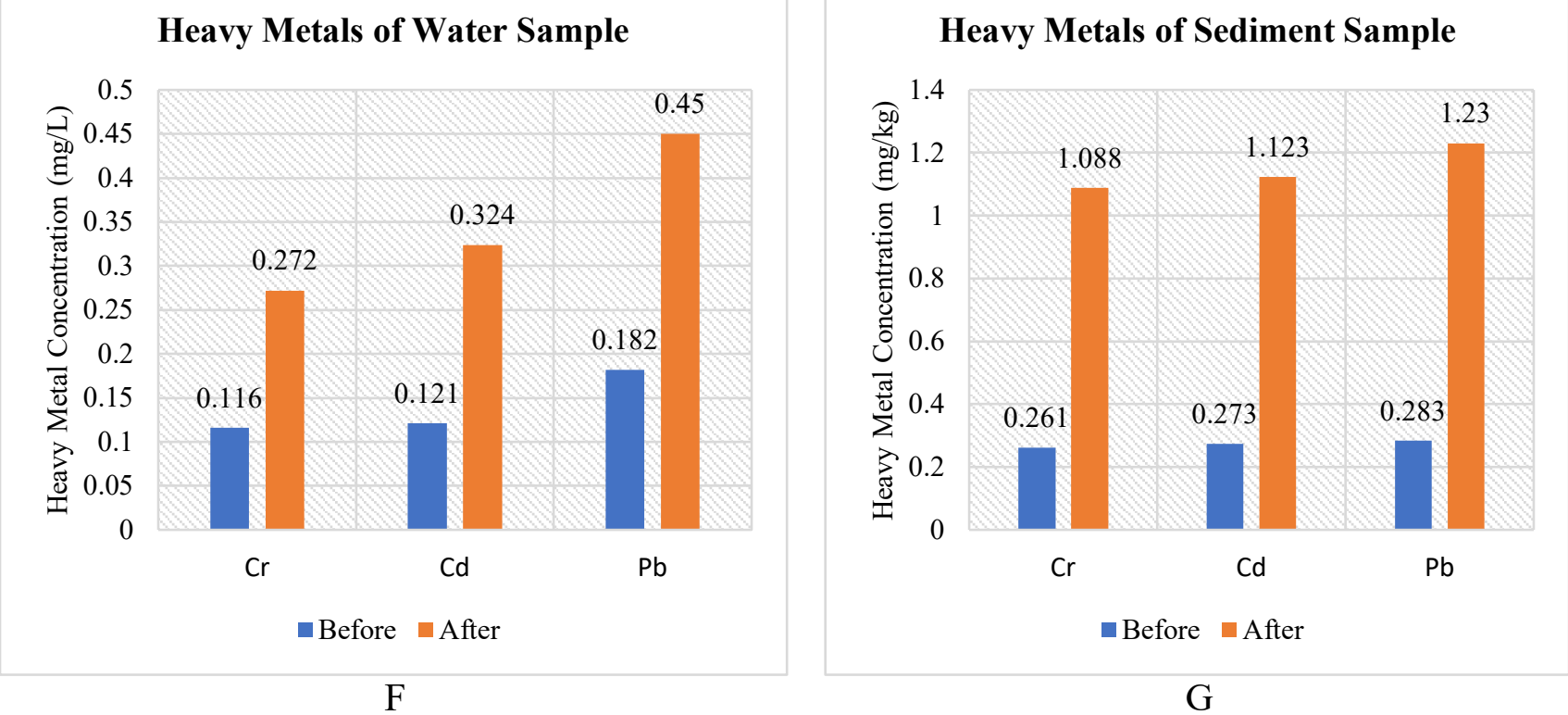

Figure-3: A. pH of water and sediment sample B. Temperature of water and sediment sample C. TS, TDS \& TSS of water sample D. Electrical Conductivity (EC) of water and sediment sample E. Heavy metals of water sample F. Heavy metals of sediment sample.

Electrical Conductivity (EC): Electrical conductivity which is indirectly significant factor for analysing the water and sediment quality and indicated that the concentration of salt concentration in water as well sediment samples. In this study, EC values varied from pre immersion $151 \mu \mathrm{S} / \mathrm{cm}$ and post immersion $537 \mu \mathrm{S} / \mathrm{cm}$ in the collected water sample, sediment sample varied from pre immersion $2800 \mu \mathrm{S} / \mathrm{cm}$ and post immersion $3800 \mu \mathrm{S} / \mathrm{cm}$ (Figure 3-D). If compared to the time of pre and post immersion periods, EC has continuously to increases in both water and sediment at sampling point. However, in the pre immersion time EC values are shoes that bellow the standards of the permissible limit but higher in the post immersion in this sampling station.

Heavy Metals: Heavy metals are used in idol making which are immersed in water their content increase in water. The levels of dissolved $\mathrm{Cr}, \mathrm{Cd}$ and $\mathrm{Pd}$ during the pre-immersion and post immersion time of periods for selected sampling site of this river Mayurakshi are presented in Figures 3E and 3F. In the pre immersion time order of dissolved metals in the selected point shows that $\mathrm{Pb}>\mathrm{Cd}>\mathrm{Cr}$ in both of the water and sediment respectively. In this present investigation, heavy metals such as $\mathrm{Cr}, \mathrm{Cd}$ and $\mathrm{Pb}$ in water was found to be time of pre immersion 0.116 , 0.121 and $0.182 \mathrm{mg} / \mathrm{L}$ and post immersion $0.272,0.324$ and $450 \mathrm{mg} / \mathrm{L}$ respectively. In sediment sample was found to be pre immersion for $\mathrm{Cr}, \mathrm{Cd}$ and $\mathrm{Pb}$ is $0.261,273$ and $283 \mathrm{mg} / \mathrm{kg}$ and post immersion 1.088, 1.123 and 1.230 $\mathrm{mg} / \mathrm{kg}$ respectively. For this sampling station, the levels of increase of $\mathrm{Pb}$, $\mathrm{Cd}$ and $\mathrm{Cr}$ are $147.25 \%, 167.77 \%$ and $134.48 \%$ respectively in water and $334.63 \%, 311.35 \%$ and $316.85 \%$ respectively in sediment. It is clear from the data sets that there has been considerable increase in the levels of dissolved heavy metals after the process of immersion of Durga idols. The results are continuously changing in the ionic concentration of the river water as well as sediment which adversely effect of some aquatic species [4]. However, in both of the cases scientifically heavy concentration is higher than the standard permissible limit. Here, $\mathrm{pH}$ value decreasing in both of the river water and sediment after the adsorption of the dissolved metals and after increase the mobility of heavy metals $\mathrm{Cr}, \mathrm{Cd}$ and $\mathrm{Pb}$ [5]. The present investigation of this sampling point reveals that immersed of idols decrease in $\mathrm{pH}$ and another side increase in metal concentration which is likely to be mobile and move on the contaminated slowly to the ground water.

Lead is generally used for paints which generally used in made for idols. It is poisoning may cause in both children to adult persons in harmful effects like as disturbing of whole nervous system where affected in the sleeplessness, restlessness, behavioural changes, learning, abnormalities and cause skin disease [6], [10]. The intake of chromium in highly amounts has adversely effects of the health for human bodies like renal, hepatic and gastrointestinal damages [11], [12], [13], [14], [15], [16], [17], [18], [19]. Cadmium when contaminated with food and water 
for a longest time of period after the results showed in the bioaccumulation in the kidney as well as liver causing severe damage to these systems and hypertension [7].

Relationship between the ground water and surface flowing of river water occurring across a separation zone within the beds of the river. In case of the river, mixing between groundwater and surface water present in the hyporheic zone [8]. The physicochemical characterization of the collected in both of the soil and water samples of this river contaminants are determine that their mobility and adversely toxic effect. Increasing in the pollution level of the river Mayurakshi due to their immersed of idols by local public near Saithia which can be one of the proper reasons for contaminated high concentration level this three heavy metals as $\mathrm{Cr}, \mathrm{Cd}$ and $\mathrm{Pb}$ in the ground water in the region surrounding the idol immersion point. Release of the $\mathrm{Cr}$ and $\mathrm{Pb}$. Above the analysed results showed in the increase in aerobic condition of both water and sediment, but Cd increase in the anaerobic condition of water and in this sampling point [9]. Therefore, in this study suggested that the authorities for looking into the environmental as well as the river Mayurakshi protection for need to take necessary action.

\section{IMPORTANT FINDINGS}

- All above the result shows that maximum physicochemical parameter values are higher than the permissible limits of the water and sediment quality of the fresh water.

- In most of the cases after immersion physicochemical parameter values shows that higher than the permissible limits.

- Heavy metals like $\mathrm{Cr}, \mathrm{Cd}$ and $\mathrm{Pb}$ is higher than the permissible limit in both of the cases.

\section{CONCLUSION}

The present investigation of the river Mayuakshi for impact on the water bodies as well as river bed i.e. sediment quality before and after immersion of Durga idols. Above the results showed that the negative impact based on their various physicochemical properties. The making for idols are used in various organic and inorganic materials, these materials are mixed in the water bodies and precipitated in the river bed. The scientific point of view based on this physicochemical properties Mayurakshi river water are not suitable for human uses. This religious activity cannot stop but some creative uniquely eco-friendly methods for making the idols where only used in the natural colours so that can be solve in this pollution problem in the river Mayurakshi.

\section{SOURCES OF FUNDING}

None.

\section{CONFLICT OF INTEREST}

None.

\section{ACKNOWLEDGMENT}

The authors would like thankful to CSIR, Pusa, New Delhi as well as DST PURSE-II West Bengal for funding agency and University of Kalyani for providing research laboratory.

\section{REFERENCES}

[1] Trivedy P.K. and Goel R.K., Chemical and Biological methods water pollution studies, Environmental publication Karad India (1986).

[2] APHA, Standard methods for examination of water and waste water, American Public Health Association, Washington, D.C., 21st Edition (2005). 
[3] Zheljzkov, V.D, Nielson, N.E., 1996. Effect of heavy metals on peppermint and cornmint. Plant Soil 178, 5966.

[4] Weber-Scannell, P.K. and Duffy, L.K., Effects if Total Dissolved Solids on Aquatic Organisms: A Review of Literature and Recommendation for Salmonid Species. American Journal of Environmental Sciences, 3(1) (2007): 1-6.

[5] Borma, L.D.S., Ehrlich, M. and Barbosa, M.C., Acidification and release of heavy metals in dredged sediments. Canadian Geotechnical Journal, 40(6) (2003): 1154-1163.

[6] Haileslassie, T. and Gebremedhin, K., Hazards of Heavy Metal Contamination in Ground Water. International Journal of Technology Enhancements and Emerging Engineering Research, 3(2) (2015): 1-6.

[7] Haiyan Li, Anbang Shi, Mingyi Li, and Xiaoran Zhang, Effect of pH, Temperature, Dissolved Oxygen, and Flow Rate of Overlying Water on Heavy Metals Release from Strom Sewer Sediments. Journal of Chemistry. http://dx.doi.org/10.1155/2013/434012, (2013): 1-11.

[8] Biksey T.M. and Gross, E.D., The Hyporheic Zone: Linking Ground Water and Surface Water-Understanding the Paradigm. Remediation/Winter. John Wiely \& Sons. (2001).

[9] Momodu, M.A. and Anyakora, C.A., Heavy Metal Contamination of Ground Water: The Surulere Case Study. Research Journal Environmental and Earth Sciences 2(1) (2010): 39-43.

[10] Reddy, V.M. and Kumar, V.A. (2001) Effect of Ganesh Idol Immersion on some water quality parameters of Hussain Sagar, Current DScience, Vol.18:1412.

[11] D.S. Bhargava, "Water quality variations and control technology of Yamuna River", Environmental Pollution Series A: Ecological and Biological, 37 (4), 355-376 (1985).

[12] A. Mehra, M. E. Farago, D. K. Banerjee, "A study of eichhornia crassipes growing in the overbank and floodplain soils of the River Yamuna in Delhi, India”, Environmental Monitoring and Assessment, 60 (1), 2545 (2000).

[13] S. Dhote, B. Varghese, S. M. Mishra, "Impact of idol immersion on water quality of twin lakes of Bhopal", Indian Journal of Environment Protection, 21, 998-1005 (2001).

[14] S. Pandey, S. Parvez, I. Sayeed, R. Haque, B. B. Hafeez, S. Raisuddin, "Biomarkers of oxidative stress: a comparative study of river Yamuna fish Wallago attu (Bl. \& Schn.)”, Science of the Total Environment, 309 (1-3), 105-115 (2003).

[15] R. Paliwal, P. Sharma, A. Kansal, "Water quality modeling of the river Yamuna (India) using QUAL2E- UNCAS", Journal of Environmental Management, 83 (2), 131144 (2007).

[16] A. Rahman, "A GIS based DRASTIC model for assessing groundwater vulnerability in shallow aquifer in Aligarh, India", Applied Geography, 28 (1), 32-53 (2008).

[17] A. Kumar, B. S. Bisht, V. D. Joshi, A. K. Singh, A. Talwar, "Physical, chemical and bacteriological study of water from rivers of Uttarakhand”, Journal of Human Ecolology, 32 (3), 169-173 (2010).

[18] A. Agarwal, R. S. Pandey, B. Sharma, "Water pollution with special reference to pesticide contamination in India", Journal of Water Resource and Protection, 2 (5), 432 - 448 (2010).

[19] A. K. Gupta, K. Mishra, P. Kumar, C. Singh, S. Srivastava, "Impact of religious Activities on The Water Characteristics of Prominent Ponds at Varanasi (U.P.), India”, Plant Archives, 11 (1), 297-300 (2011).

[20] ICMR, Manual of standards of quality for drinking water supplies, Special report series No.44, 2nd Edition (1975).

[21] BIS, Indian Standards Specification for drinking water IS: 10500. New Delhi: Bureau of Indian Standards (2003). 